Journal of Contemporary Research in Social Sciences

ISSN : 2641-0249

Vol. 1, No. 5, pp. 114-125

2019

Publisher: Learning Gate

DOI: $10.33094 / 26410249.2019 .15 .114 .125$

(C) 2019 by the authors; licensee Learning Gate

\title{
Achieving Sustainable Growth in Developing Countries, Does Export Really Matter?
}

\author{
Richardson Kojo Edeme \\ Department of Economics, University of Nigeria, Nsukka, Nigeria \\ Sunny O Ijieh \\ Department of Economics, College of Education, Agbor, Nigeria \\ Nelson C Nkalu \\ Department of Economics, University of Nigeria, Nsukka, Nigeria
}

Received: 19 July 2019; Revised: 27 August 2019; Accepted: 6 September 2019; Published: 16 September 2019

\begin{abstract}
This study tries to ascertain if export really matter in developing countries quest to achieving sustainable growth using Nigeria case study. With the Toda-Yamamoto Granger Causality framework, the study found that as variables that influences growth, export and import are significant in accentuating sustainable growth. In specific terms, on the average, a percentage increase in export stimulates economic growth by 2.45 while a percentage increase in import dampens economic growth by about 0.23 percent. The direction of causal relationship suggests that there is unidirectional causality running from export to economic growth suggesting the existence of export-led growth hypothesis for Nigeria. Also, there exists unidirectional causality running from export to economic growth an indication that the causality running from export to economic growth is the strongest, revealing that export-led growth hypothesis holds for Nigeria. This suggests that to achieve sustainable growth in Nigeria, it is necessary to encourage export, although emphasis should also be on import restrictions through the provision of transparent regulatory policy and framework.
\end{abstract}

Keywords: Export, Export-led growth hypothesis, Growth-led export hypothesis, Sustainable growth, Toda-Yamamoto Granger Causality framework

JEL Classification: C31, F43, O13, O47

\section{Introduction}

The desire of developing countries is to achieve sustainable growth and become leading economies in the world in the nearest future. In achieving this, a basic question is, does export really matter? Discussions on the effect of export on growth have thrown up discussions as whether export stimulates growth or growth stimulates export, especially in developing countries of Africa. This contraction gives credence to further provide empirical evidence on whether export really matter in the attainment of sustainable growth using data from Nigeria. In determining the relationship between export and growth, the neoclassical found a substantial positive impact of export and trade on economic growth. To the proponents of the two-gap model, they assert that exports play a positive role on economic growth due to accumulation foreign reserve associated with export. But the Marxist expressed a different view because to them, export trade is a channel through which industrialized nations uses to exploit the developing countries.

A critical review of literature revel that two hypotheses exist: the export-led growth hypothesis and growth-led export hypothesis. The export-led growth hypothesis (ELGH) postulates that increase 
export stimulates economic growth, thus emphasizing the importance of export in engendering economic growth. The assertion is that export-oriented policies act as catalyst to output growth through efficient resource allocation, greater capacity utilization and exploitation of economies of scale, technological improvement and diffusion of technical knowledge. In support of this thesis, Mishra (2011) argue that causality runs from economic growth to exports. Implied here is that improve export engenders economic growth. On the converse, the two way causal hypothesis, which is bi-directional, reveal that export and economic growth complement each other, that is, causality runs from both directions. Consequently, Maneschiold (2008) suggest that policies geared towards the attainment of high economic growth should focus on output and export expansion.

Conesus on export-led growth hypothesis became prominent after the successful story of the newly industrialized countries of Asia, hence, the notion among some researchers and policy makers that developing countries can achieve economic growth through export promotion, citing the case of the Gang of Four ${ }^{1}$ that have been able to attain and consistently maintained high levels of economic growth since the 1960s, fuelled by exports and rapid industrialization (Yelwa \& Diyoke 2013). In lie with this, developing countries have introduced different policies and strategies to encourage export because of its role in promoting price stability, sustainable output growth as well as income and employment generation. In agreement with this, Ahmad \& Harnhirum (2009) asserts that the economic success attained by the Asian newly industrialized countries has provided impetus to all countries in the South East Asian Nations to adopt and pursue aggressive export promotion strategies. But while empirical evidence in support of export-led growth may not be universal, rapid export growth has been an important feature of East Asia's remarkable record of high and sustained growth. In these countries, export have stimulated growth through a variety of ways including production and demand linkages, economies of scale due to larger international markets, increased efficiency, adoption of superior technology embodied in foreign-produced capital goods, learning effects and improvement of human resources, increased productivity (Liu, 2007; Giles \& Williams, 2000, Sahni, 2012).

Discussions on ELGH can also be approached from the wider view on trade openness and economic growth. Adopting this approach, Martin (2001) and Masson (2001) contends that what appears to be gaining prominence in recent cross-country growth differences is that most of them that have witnessed unprecedented growth have taken advantage of international trade. This evidence in favour of ELGH and global trend towards trade liberalization appears to seem to have influenced many developing countries such as Kenya in the adoption of an export-led growth strategy embedded in the country's poverty reduction strategy framework. However, in most of these countries, there is often very low domestic demand such that exports remain one of the few channels that would significantly contribute to higher income per capita growth rates of a country in the long run. Although some studies have shown that export diversification has positive effect on increased per capita income in some developing countries.

From the above, it can be inferred that in the discourse of the nexus between export and economic growth three notable hypotheses have emerged. They are the Export-Led Growth Hypothesis (ELGH), the Growth-Led Export Hypothesis (GLEH) and the two-way causal hypothesis and several studies have supported or opposed these hypotheses. To Jordan \& Eita (2010), export accelerates growth through technological spill-over and other externalities. This occurs when export industries are considered a key sector of the economy. The implication of this is that an export-led growth strategy aims at providing producers with incentives that encourages exports. This approach is aimed at increasing the capability of producing goods that can compete in the world market using advanced technology and provision for foreign exchange needed to import capital goods. Taban \& Aktar (2008), Abdulnasser \& Manuchehr (2000) and are of the view that export-support policies contribute to economic growth through various ways: First an increase in export leads to output expansion through foreign trade multiplier. Second, export relaxes the binding foreign exchange constraint to ease import of capital and intermediate goods which lead in turn to economic growth. Third, export increase efficiency through competition which in turn gives rise to economies of scale and diffusion of the 
technical knowledge in production, which is potentially an important ingredient for growth. Giles \& Williams (2000) contend that China's experience during the 1980s and 1990s tend to support the argument that openness to trade is a mechanism for achieving more rapid and efficient growth with better distribution of resources. Supporting Krueger (1995); Finlay \& Watson (1996), Chong, Yusop \& Law, (2007); Rahmanddi \& Ichinashi, (2011), Veulemans (2012) identified trade policy as the crucial element of economic policy in the growth equation citing the example of Gang of Four that have been successful in achieving high and sustained rates of economic growth because of their free-market, outward-oriented policies. Several other studies have also come to conclusion that growth stimulates export. They however expressed fear that reliance on export to drive the economy may not result in the desired sustained growth, especially in Less Developed Countries (LDCs) due to volatility and unproductive nature of the market. Beside, most of these countries are consumer nations rather than producer nations and are therefore exposed to the vagaries of the world market. This view was supported by Veulemans (2012) when he asserts that growth causes exports when natural resources are in abundance and fully harnessed in domestic economies.

Although theoretical insight would be valuable in the study of the link between export and growth, but despite series of studies conducted in Nigeria, it is difficult to generalize the outcome due to the methodology adopted. With the implementation of the new export policy and the quest to attain desired growth, it is imperative to examine the relationship between export and economic growth in Nigeria with a view to ascertain if export-led growth hypothesis hold for Nigeria, Our analysis is based on the Toda-Yamamoto co integration framework. This approach offers a better insight in providing appropriate and useful policy measure to address some of the export and import challenges in the face of attaining sustainable growth

\section{Literature Review}

Studies that lend support for the export-led growth hypothesis include Maneschiold (2008) that employed co-integration test to show that there is a long-run relationship between economic growth and export for Argentina and Mexico. Applying both the Johansen co-integration approach and accounting, Mohammed, Saafi \& Farhat (2014) also found significant evidence on export-led growth for Tunisia. The study by Whiteman, Sumer \& Riezman (1995) employed measure of conditional linear feedback and found a causal ordering from export growth to income growth in 65 out of the 126 countries. More so, Shirazi \& Manap (2004) use data from1960- 2003 for Pakistan and Sri-Lanka to analyze the relationship between export and economic growth based on co-integration and multivariate Granger causality framework and found a unidirectional causality from export to growth. Similarly, Anwar \& Sampath (2000) examined the export-led growth hypothesis for 97 countries and found evidence of unidirectional causality in the case of Pakistan and Sri Lanka and no causality for India. Shahbaz (2012) adopted the Mankiw framework and examined the effect of trade openness on Pakistan economic growth. The result of the Granger causality test supports the growth-led hypothesis. Similarly, Bhati (1995) examined the exports-economic growth nexus for India, and found evidence of bi-directional causality between growth of exports and economic growth. To Xu (1996), the export-led growth hypothesis does not hold for India, thus growth of export is caused by economic growth in the country. Similarly, Dreger \& Hezer (2012) studied for the period 1961-1993 and found that growth in GDP causes growth in export while the causality that runs from export to GDP appears to be in the short run. Nain \& Ahmad (2010) employed the granger causality test and error forecast for 14 years to further support the growth-led Hypothesis in Indian. Zapata \& Rambaldi (2011) provide evidence of both hypotheses using the modified Granger causality test when he found that export causes growth just as growth causes export. Amavilah (2003) study for Namibia support the general importance of exports in stimulating growth but find no discernible sign of accelerated growth attributable to exports. Thurayia (2004) conducted a study on the relationship between exports and economic growth in Saudi Arabia and Sudan and found that the growth rate in total exports in Saudi Arabia had an active role in achieving economic growth, while it had a weak influence in Sudan. This result confirms the validity of 
the export-led growth hypothesis for both countries. Yousif Khalifa Al-Yousif (1997) investigated the relationship between exports and economic growth in Saudi Arabia, Kuwait, UAE and Oman using panel data. Although the result indicates a positive and significant relation between the variables, no causality was established. Hamed and Devi (2012) investigated the causality between exports and economic growth of Pakistan through the application of econometric technique Granger causality using real exports, real GDP and real terms of trade based on annual data from 1960 to 2009. The empirical results from Granger causality technique clearly indicated that there exists unidirectional causality from GDP to exports in Pakistan and not vice versa. A major conclusion arrived by this study is that policy makers need to promote export expansion policies with the aim of achieving high economic growth. Alhakimi (2018) carried out a study with the primary objective of investigating the relationship between exports and economic growth in the Kingdom of Saudi Arabia. Four main propositions for the relationship between exports and economic growth were formulated: export-led growth, growth-driven exports and feedback relationships between exports and economic growth, and empirical analysis found that economic growth significantly influence exports and not the reverse. On the performance of countries such as Turkey, Iran, Israel, Egypt and Russia that give economic and political direction to Middle East geography, Beşer and ÖKiliç (2017) however determined that bidirectional causality relationship from export to growth.

Others such as Boame (1998), Khalafalla \& Webb (2001), Konya (2004), Nain et al., (2010), Samad (2011), Alam (2011), Antri (2012) came to conclusion that export and economic growth complement each other, implying that causality runs from both directions. These studies assert that policies and programmes for the attainment of high growth should focus on export expansion. For Nigeria, Omisakin (2009) analyzed the causal and dynamic relationship between foreign trade and growth of the economy with the Autoregressive distributed lag model (ARDL) technique. The results show bidirectional relationship between export and output. Udube \& Okulegbe (2012) employed co integration to determine whether there is bi-directional relationship between exports and economic growth and thence evaluated the significant impact of exports on the economic growth in Nigeria. The study found that there exist a long-run relationship between economic growth and export. Also, imports and exchange rate were positively correlated with GDP while export was negatively related with GDP. The last strand of studies found no evidence of causal relationship between export and economic growth. Studies in this group include Jung \& Marshall (1985), Darrat (1986) and Sharma Panagiotidis (2005). For Hong-Kong, South Korea and Singapore, the Granger causality tests found no causal effects running from exports to economic growth or vice-versa. In all the countries economic growth and export are causally independent.

\section{Methodology}

From empirical literature and in terms of methodology, studies in this area can be grouped into two. The first category employed the traditional econometric technique based on single equation or multiple equation models while the second group used econometric techniques based on vector autoregression (VAR) in which issues of co integration and causality are considered. In the application VAR, both the dependent and independent variables are often treated on equal footing. Unlike the single equation model where the relationship has dependent and explanatory variable(s) and the value of the dependent variable id determined or influenced by the explanatory variable(s).

Given two variables $X$ and $Y$ having $K$ lag values of $X$ (as measured by $X_{\imath}$ ) in which $X$ influences $Y$ and $Y$ influences $X$, then each of the relationship can be modeled as:

$$
X_{i t}=\omega+\sum_{j=1}^{k} b i_{j} X_{t-j}+\sum_{j=1}^{k} \delta_{j} Y_{t-j}+U_{1 t}
$$




$$
Y_{t}=\omega 1+\sum_{j=1}^{k} \varphi_{j} Y_{t-j}+\sum_{j=1}^{k} \delta_{j} Y_{t-j}+U_{2 t}
$$

where $\omega, b$ and $\varphi=$ parameters to be estimated; $X_{t}-X_{t-j}\left(\Delta X_{t}\right)=$ first difference of the series; $U_{s}^{\prime}=$ stochastic error terms, known as impulses or shocks; $k=$ lag length and $t=$ time period (year). As a requirement, the stationarity of the series are conducted, employing one or combination of two of such test as Augemented Dickey Fuller (ADF) test, Philip-Perron (P-P) test. Such test can be performed on both the level and first differenced observation by estimating three different models under three conditions as: No constant and no trend; Constant and no trend and Constant and trend. In specific terms, these models can be stated separately as:

$$
\begin{aligned}
& \Delta X_{t}=\delta X_{t-1}+\sum_{i=1}^{k} F_{i} \Delta X_{t-1}+U t \\
& \Delta X_{t}=\beta_{0}+\delta X_{t-1}+\sum_{i=1}^{k} F_{i} \Delta X_{t-1}+U t \\
& \Delta X_{t}=\beta_{0}+\beta_{2} t+\delta X_{t-1}+\sum_{i=1}^{k} F_{i} \Delta X_{t-1}+U t
\end{aligned}
$$

where $X_{t}-X_{t-1}=\Delta X t$ (first difference of the series); $F, \delta$ and $\beta=$ parameters to be estimated $\mathrm{k}$, $t$ and $U$ 's as previously defined.

\subsection{Model Specification}

The standard methodology of growth model begins with the neoclassical function in which aggregate real output is determined by capital stock, labour and their efficiency. But the emergence of endogenous growth theory and model (eg, Romer 1986 \& Barro 1991) suggests that other endogenous factors such as government policies (government expenditure, tax, import policies) can also affect growth. Accordingly, several studies have attempted to integrate exogenous with endogenous variables in explaining economic growth. The growth model extended by Mankiw, Romer \& Weil (1992) which included human capital can be expressed as.

$$
\gamma=A C^{\alpha}(h L)^{\beta}
$$

vi

The above equation when expanded can be stated as:

$$
r=f(A, C, h L)
$$

vii

where $\mathrm{Y}=$ Output, $\mathrm{C}=$ Capital, $\mathrm{h}=$ human capital, $\mathrm{L}=$ Labour

Leaning on the above, to explain the association between economic growth and export, this study postulates a specification based on Shirazi \& Manap (2004) as:

$E C G_{t}=f\left(E X P_{t}\right)$

vii

Given that production activities in a developing country like Nigeria heavily depends on imported inputs, equation (vii) is augmented with import variable to become:

$E C G_{t}=f\left(E X P_{t}, I M P_{t}-G D P_{t}\right)$

$i x$ 
When liberalized, we have:

$\log E C G_{t}=\alpha_{o}+\beta_{1} \log E X P_{t}+\beta_{2} \log \left(I M P_{t}-G D P_{t}\right)+e_{t}$

$x$

where $\mathrm{ECG}=$ economic growth (proxied by gross national product (GNP), EXP $=$ export, IMP-GDP = import-GDP, e = error terms which captures the effect of other variables not included in the model

\subsection{Estimation Technique}

In conducting co integration analysis, various techniques can be adopted such as the residual-based approach proposed by Engle \& Granger (1987) and the maximum likelihood-based approach credited to Johansen \& Julius (1990) and Johansen (1992), among others, this study adopts the autoregressive distributed lag (ARDL) bounds method. This approach is superior to other co integration methods because it does not consider the degree of integration of the variables under consideration and thus avoid the pre-testing of the order of integration of the variables. Also it allows the simultaneous estimation of both the short-run and long-run parameters since it takes into consideration the error correction term in its lagged period. Thirdly, the ARDL approach is more robust and performs better for small sample sizes. The ARDL approach requires estimating the conditional error correction version of the ARDL model for variables under estimation. In line with ARDL, our model specified above can be modified as:

$$
\begin{aligned}
\Delta E C G_{t}=\beta_{1}+ & \beta d i \hat{\delta}_{t-1}+\sum_{i=1}^{k} \beta_{1}(i) \Delta E X P_{t-1}+\sum_{i=1}^{k} \beta_{2}(i) \Delta E X P \\
& +\sum_{i=1}^{k} \beta_{3}(i) E C G_{t-1}+I M P t-1+U_{1} t+\beta 4 E C G+\text { Uit } \ldots \ldots \ldots \ldots
\end{aligned}
$$

Here, $\beta_{i}$, are parameters to be estimated

The error correction (EC) representation of the ARDL model can be obtained by writing Equation (xi) in terms of the lagged levels and the first differences of the variables under consideration as:

$$
\begin{aligned}
& \Delta E C G_{t}=\beta_{1}+\beta d i \hat{\delta}_{t-1}+\sum_{i=1}^{k} \beta_{1}(i) \Delta E X P_{t-1}+\sum_{i=1}^{k} \beta_{2}(i) \Delta E X P+\sum_{i=1}^{k} \beta_{3}(i) E C G_{t-1}+I M P t- \\
& 1+U_{1} t+\beta 4 E C G+U i t+\chi E C M i-j
\end{aligned}
$$

where $\chi$ is the speed of adjustment, $\mathrm{ECM}_{\mathrm{t}-1}$ is error correction term lagged by one-time period and $\Delta$ first difference operator. Although, different approaches can be used to conduct Granger causality test, Phillips \&Toda $(1993,1994)$ argue that VAR estimation often entails nuisance parameters and in this regard, no satisfactory basis for mounting a statistical test of causality test applies since the F-test statistic does not have a standard distribution when variables are integrated. To overcome this problem, we adopted the modified Granger causality methodology developed by Toda \& Yamamoto (1995) causality approach. It is a procedure requiring the estimation of an augmented VAR, which guarantees the asymptotic distribution of the MWald statistic. Zapata \& Rambaldi (1997) provided evidence that the MWALD test has a comparable performance in size and power to the LR and WALD tests. The basic idea behind the Toda-Yamamoto framework is to augment the correct VAR order, $\mathrm{k}$ with $d m$ extra lags (the maximum likely order of the time series in the system). In line with the foregoing, equation (xii) above can be re-specified using the lag augmented VAR representation as:

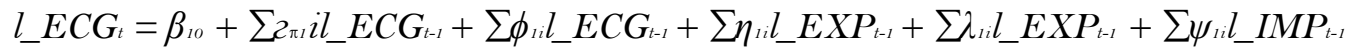

$$
\begin{aligned}
& +\sum \rho_{i i} l_{-} I M P_{t-1}+\varepsilon 1 \mathrm{t} \quad \text {........................................ Xiiia } \\
& l \_E X P t=\beta_{20}+\sum 2_{2 i} i l_{1} E C G_{t-l}+\sum \phi_{2 i} l_{-} E C G_{t-l}+\sum \eta_{2 i} l_{-} E X P_{t-l}+\sum \lambda_{2 i} l_{-} E X P_{t-l}+\sum \psi_{2 i} l_{1} I M P_{t-l}
\end{aligned}
$$


$1 \_\mathrm{IMPt}=\beta_{30}+\sum_{2 s i} i l_{-} E C G_{t-l}+\sum \phi_{s i} l_{-} E C G_{t-l}+\sum \eta_{s i} l_{-} E X P_{t-l}+\sum \lambda_{s i} l \in E X P_{t-l}+\sum \psi_{s i} l_{-} I M P_{t-l}$ $+\sum \rho_{s i} l_{-} I M P_{t-1}+\varepsilon s t$

where $2, \phi, \eta, \lambda \psi$ and $\rho$ are parameters, $p$ is the true lag length, $\varepsilon^{t h} \varepsilon^{2 t}$, and $\varepsilon^{s t}$ are the residuals. Equations (Xiiia), (Xiiib) and (Xiiic) are to determine the direction of causality between export and economic growth.

In our analysis, the Toda \& Yamamoto procedure is applied using MWald tests to verify if the coefficient of the lagged values is significantly different from zero in equations xiiia, xiiib and xiiic. This test restricts the associated parameters of the explanatory variables to zero. It is also often imperative to know the response of one variable to an impulse in another variable in a system that involves a number of further variables which requires the determination of the impulse response relationship between two variables. To this end, the generalized impulse response which is invariant to the ordering of the variables in the VAR is used. To infer the degree of erogeneity of the variables beyond the sample period, the decomposition of variance which measures the percentage of a variable's forecast error variance that occurs as the result of a shock from a variable in the system is considered. Data for this study are annual time series generated from Central Bank of Nigeria Statistical Bulletin and National Bureau of Statistics Annual Abstract of Statistics.

\section{Results and Discussion}

\subsection{Unit Root Test Result}

Using ADF and PP unit root tests, the result in Table 1 below shows that the variables are nonstationary at their levels but stationary at first differences, being integrated of order one, I(1).

Table 1.

Unit Root Test Results

\begin{tabular}{|c|c|c|c|c|c|}
\hline & Test & ADF & & PP & \\
\hline Variables & & $\begin{array}{l}\text { Intercept and } \\
\text { no Trend }\end{array}$ & $\begin{array}{l}\text { Intercept and } \\
\text { Trend }\end{array}$ & $\begin{array}{l}\text { Intercept and } \\
\text { no Trend }\end{array}$ & Intercept and Trend \\
\hline \multirow{3}{*}{ Level } & ECG & $\begin{array}{l}-0.1201,[1] \\
(-2.931)\end{array}$ & $\begin{array}{l}-1.6226,[1] \\
(-3.518)\end{array}$ & $\begin{array}{l}-0.1201,[1] \\
(-2.931)\end{array}$ & $\begin{array}{l}-1.7891,[1] \\
(-3.518)\end{array}$ \\
\hline & EXPT & $\begin{array}{l}0.8579,[1] \\
(-2.143)\end{array}$ & $\begin{array}{l}-3.3224,[1] \\
(-3.523)\end{array}$ & $\begin{array}{l}0.7422,[1] \\
(-2.931)\end{array}$ & $\begin{array}{l}-3.5000,[1] \\
(-3.518)\end{array}$ \\
\hline & IMP & $\begin{array}{l}0.9542,[1] \\
(-2.082)\end{array}$ & $\begin{array}{l}-3.5181,[1] \\
(-8.585)\end{array}$ & $\begin{array}{l}0.8721,[1] \\
(-2.798)\end{array}$ & $\begin{array}{l}-8.8543,[1] \\
(-3.652)\end{array}$ \\
\hline \multirow{3}{*}{$\begin{array}{l}\text { First } \\
\text { Difference }\end{array}$} & $\Delta \mathrm{ECG}$ & $\begin{array}{l}-6.5523,[1] \\
(-3.521)\end{array}$ & $\begin{array}{l}-6.5571,[1] \\
(-3.521)\end{array}$ & $\begin{array}{l}-6.5523,[1] \\
(-2.933)\end{array}$ & $\begin{array}{l}-6.5571,[1] \\
(-3.521)\end{array}$ \\
\hline & $\triangle \mathrm{EXPT}$ & $\begin{array}{l}-8.6866,[1] \\
(-2.933)\end{array}$ & $\begin{array}{l}-8.6866,[1] \\
(-3.521)\end{array}$ & $\begin{array}{l}-9.9507,[1] \\
(-2.933)\end{array}$ & $\begin{array}{l}-8.5852,[1] \\
(-3.524)\end{array}$ \\
\hline & $\Delta \mathrm{IMP}$ & $\begin{array}{l}0.9542,[1] \\
(-2.821)\end{array}$ & $\begin{array}{l}-8.5853,[1] \\
(-1.011)\end{array}$ & $\begin{array}{l}-8.8543,[1] \\
(-3.652)\end{array}$ & $\begin{array}{l}-8.3690,[1] \\
(-2.753)\end{array}$ \\
\hline
\end{tabular}

\subsection{Co Integration Test}

Economic growth, export and import are stationary of I (1) and hence co-integration analysis is needed. Before doing this, it is necessary to perform the ARDL estimates through the diagnostic tests. A two-step procedure is used in estimating the long-run relationship. As can be seen from the result in Table $2, \mathrm{R}^{2}$ is 95 percent and it is statistically significant at 1 percent level, implying that the model fits is well established. 
Table 2.

Estimated Long run coefficients using the ARDL Approach

\begin{tabular}{|c|c|}
\hline $\operatorname{ARDL}(1,1,0,0,0)$ selected based on & chwarz Bayesian Criterion \\
\hline Dependent variable is lnECG & \\
\hline Regressor Coefficient & Standard Error $\quad$ t-Ratio[Prob $]$ \\
\hline 1_EXPt & $3.5671[.000]^{*} *$ \\
\hline $1 / \mathrm{IMP}_{\mathrm{t}}$ & $2.4872[.001]^{* *}$ \\
\hline-5.3464 & $-1.03561[.031]$ \\
\hline .95243 & \\
\hline S.E. of Regression & F-Stat. $\quad \mathrm{F}(2,84) \quad 351.7733[.000]$ \\
\hline Diagnostic Tests & \\
\hline Test Statistics & LM Version \\
\hline A: Serial Correlation & $\chi_{\text {auto }}^{2}(1)=.24590[.552]$ \\
\hline B: Functional Form & $\chi_{R E S E T}^{2}(1)=.0112082[.298]$ \\
\hline C: Normality & $\chi^{2}{ }_{\text {Norm }}(2)=.3452[.670]$ \\
\hline D: Heteroscedasticity & $\chi_{\text {Het }}^{2}(1)=.28902[.221]$ \\
\hline
\end{tabular}

Note: ** and * denote significant at 1percent and 5percent level. Figures in parenthesis are p-values

Table 2 shows that economic growth, export and import are co-integrated when lagged value of economic growth is taken as dependent variable. This is evidenced in F-statistic which is greater than both the 95 percent Upper Bound critical value of 4.00 and 4.78 respectively.

Table 3.

Short run dynamics result for the selected ARDL Model

ARDL(1,1,0,0,0) selected based on Schwarz Bayesian Criterion

Dependent variable is $\Delta \mathrm{l} \_\mathrm{ECG}$

\begin{tabular}{|c|c|c|}
\hline Regressor & Coefficient & Standard Error \\
\hline$\Delta \mathrm{l}_{-} \mathrm{EXP}_{\mathrm{t}}$ & 0.3456 & $2.0072[.0003]^{* *}$ \\
\hline$\Delta \mathrm{l}_{\mathrm{I}} \mathrm{IMP} \mathrm{t}_{\mathrm{t}}$ & -0.1309 & $2.3422[.0000]^{* *}$ \\
\hline $\mathrm{ECM}_{\mathrm{t}-1}$ & -0.4579 & $-3.1230[.0001]^{* * *}$ \\
\hline $\mathrm{R}^{2}$ & .78930 & \\
\hline S.E. of Regression & .071209 & $\begin{array}{lll}\text { F-Stat. } & \mathrm{F}(6,74) & 10.8922[.000]\end{array}$ \\
\hline \multicolumn{3}{|l|}{ Diagnostic Tests } \\
\hline \multicolumn{2}{|l|}{ Test Statistics } & LM Version \\
\hline \multicolumn{2}{|c|}{ A: Serial Correlation } & $\chi_{\text {auto }}^{2}(1)=.2012[.398]$ \\
\hline \multicolumn{2}{|c|}{ B: Functional Form } & $\chi^{2}{ }_{\text {RESET }}(1)=2.4453 .[.077]$ \\
\hline \multicolumn{2}{|l|}{ C: Normality } & $\chi^{2}{ }_{\text {norm }}(2)=.45760[.298]$ \\
\hline \multicolumn{2}{|c|}{ D: Heteroscedasticity } & $\chi_{\text {Het }}^{2}(1)=.032901[.677]$ \\
\hline
\end{tabular}

Note: Figures in parenthesis are p-values. $\Delta$ represents the first difference operator;

**and * denote significant at 1 percent and 5percent level respectively 
However, the lagged value of export and import as a dependent variable are not co-integrated because the calculated F-statistic is less than the 95 percent Lower Bound critical value. The existence of single co-integrating equation suggests that there is long-run relationship among the variables. The estimated coefficients show that export has positive impact on economic growth while import is negatively related to economic growth. In specific terms, an increase in export leads to 2. 56 percent increase in economic growth, keeping other things constant. Also, a percentage rise in import decreases economic growth by about 0.23 percent. The result of the short-run dynamic growth model and the various diagnostic tests is further presented in Table 3.

As revealed in Table 3, about 78 percent of the variations in economic growth is explained by explanatory variables. The estimated coefficients also reveal that export and import are statistically significant, although export has not impacted on economic growth at least in the short-run.

\subsection{Toda-Yamamoto Non-Causality Test}

For Toda-Yamamoto non-causality test, the lag length of the variables was first determined and the result is presented in Table 4.

Table 4.

VAR LAG Order selection criteria

\begin{tabular}{|l|l|l|l|l|l|l|}
\hline Lag & LogL & LR & FPE & AIC & SC & HQ \\
\hline O & 55.5210 & NA & $1.51 \mathrm{e}-08$ & -2.09921 & -2.1234 & -1.1234 \\
\hline 1 & 135.1903 & $201.0022^{*}$ & $0.09 \mathrm{e}-11^{*}$ & $-7.0234^{*}$ & $-6.9012^{*}$ & $-8.3211^{*}$ \\
\hline 2 & 167.2099 & 22.3409 & 1.7120 & -7.1098 & -5.3242 & -7.5120 \\
\hline 3 & 189.2331 & 20.5509 & 2.9022 & -7.0998 & -4.2122 & -6.0823 \\
\hline
\end{tabular}

As evidenced in Table 4, the optimal lag length is 1 since all variables become stationary after their first difference. From this, a system of VAR can be estimated in levels with a total of $\left(\mathrm{d}_{\mathrm{m}}+\mathrm{k}=1+1\right)$ which is 2 lags. Thus, the VAR model is adequate and can therefore be used for Granger causality test. Following the TYDL approach, the augmented VAR of order 2 is estimated and the Wald test is performed only on the coefficients of the first lag. The result of three variables VAR model is presented below.

Table 5.

Long-run Granger Causality based on TYDL Approach

\begin{tabular}{|l|l|l|l|}
\hline Dependent Variables & Source of Causation & & \\
\hline & l_ECG & l_EXP & 1_IMP \\
\hline 1_ECG & $\chi^{2}(1)$ & $\chi^{2}(1)$ & $\chi^{2}(1)$ \\
\hline l_EXPT & & 2.9801 & $5.2901^{* *}$ \\
\hline l_IMP & 0.2110 & & $5.2901^{* *}$ \\
\hline Note: ** implies significant at 5 percent level & 0.0120 & $6.4726^{* *}$ & \\
\hline
\end{tabular}

The result depict that the Granger causality between economic growth and export is un-directional, implying that export Granger causes economic growth, thus confirming the existence of the export-led growth hypothesis for Nigeria. This finding is in tandem with Mohammed, et al (2014) for Tunusia, Shahbaz (2012) for Pakistan Maneschiold (2008) for Argentina and Mexico, Shirazi \& Manap (2004) for Pakistan and Sri-Lanka. 


\section{Conclusion}

This paper demonstrates that both export and import plays a role in economic growth of Nigeria. As variables that determine growth, export and import are statistically significant in determining growth. In specific terms, on the average, a percentage increase in export stimulates economic growth by 2.45 while a percentage increase in import dampens economic growth by about 0.23 percent. The direction of causal relationship based on the TYDL framework suggests that there is unidirectional causality running from export to economic growth suggesting the existence of export-led growth hypothesis for Nigeria. A major policy implication from the findings is that Nigeria has to encourage export towards the attainment of the desired growth; an indication that for sustainable growth to occur in Nigeria, export should be encouraged. Such export should however not be focused on a single product, but on a variety of products, especially non-oil products. Emphasis should be on import restrictions through the provision of transparent regulatory environment policy and framework.

\section{References}

Abdulnasser, H \& Manuchehr, I. (2000). Time series evidence for Balassa's export-led growth hypothesis, Journal of International Trade \& Economic Development, 1(4)

Abou-Stait, F. (2005). Are exports the engine of economic growth? An application of cointegration and Causality Analysis for Egypt, 1977-2003, Economic Research Working Paper Series, Tunis: African Development Bank

Ahmad, J \& Harnhirum, S. (2009). Co integration and causality between exports and economic growth: Evidence from the ASEAN Countries, The Canadian Journal of Economics, 29. Retrieved from http://www.jstor.org/stable/136078

Alam, H.M. (2011). An econometric analysis of export-led growth hypothesis: Reflections from Pakistan, Interdisciplinary Journal of Contemporary Research in Business, 2(12)

Alhakimi, S. S. (2018). Export and economic growth in Saudi Arabia: The granger causality test, Asian Journal of Economics E Empirical Research, 5 (1), 29-35, doi: 10.20448/journal.501.2018.51.29.35

Amavilah, V. H. (2003). Exports and economic growth in Namibia, 1968-1992, Economic Working Paper Series

Anwar, M.S \& Sampath, R. K. (2000). Exports and economic growth, Indian Economic Journal, 47(3)

Beşer, M \& ÖKiliç, N. Ö (2017). Analysis about export and economical growth of countries that give economic and political direction to Middle East geography, Microeconomics Eं Macroeconomics, 5 (1), 1-5, doi: 10.5923/j.m2economics.20170501.01

Bhati, S. (1995). Export and economic growth in India, Artha Vijana, 37

Boame, R. (1983). Exports and economic growth in Indonesian: A causality approach based on multivitiate error correction model, .Journal of International Development E Cooperation, 17 (2), 53-73

Choong, C.K , Z. Yusop, Z \& Law, S. H (2007). Export-led hypothesis: New evidence from Thirwall's Idea, The Philippine Review of Economics, XLIV(1)

Darrat, A.F (1986). Trade and development: The Asian experience, Cato Journal, 6

Dreger, C \& Herzer, D. (2012). A further examination of the export-led growth hypothesis, FIW Working Paper, 84. Retrieved from http://hdl.handle.net/10419/49532

Finlay \& Watson, F. (1996). Trade policy and economic growth in South Korea, South Asia Economic Journal, 8(1)

Giles, J. A. \& Williams, C. L (2000). Export-led growth: A survey of the empirical literature and some non-causality results Part 1, University of Victoria

Hameed, I \& Devi, F (2012). Relationship between exports and economic growth of Pakistan, European Journal of Social Sciences, 32 (3), 453-460

Johansen, S. (1998). Statistical analysis of cointegrating vectors, Journal of Economic Dynamics E Control, (12) 
Jung, W \& Marshall, P. (1985). Exports, growth and causality in developing countries, Journal of Development Economics, 18

Khalafalla, K. Y \& Webb, A. J (2001). Export-led growth and structural change: Evidence from Malaysia, Applied Economics, 33

Kónya, L (2004). Export-led growth, growth-driven export, both or none? Granger causality analysis on OECD countries, Applied Econometrics \& International Development, 4(1)

Krueger, A.O (1995). The experience and lessons of Asia super exporters, In: Corbo,V.,Krueger, A.O. and F. Ossa (eds.), Export-oriented Development Strategies, The Success of five newly industrialized countries, London, Westview Press

Liu, T. (2007). Exploring exports and economic growth causality in Algeria, Journal of Economic \& Behavioural Studies, 2(3), 92-96

Marin, D (1992). Is the export-led growth hypothesis valid for industrialized countries?, Review of Economics and Statistics, 3 (1)

Maneschiöld, P.O. (2008). A note on the export-led growth hypothesis: A time series approach, Cuadernos De Economíal, 45

Mishra, P.K (2011). The dynamics of relationship between export and economic growth in India, International Journal of Economic Sciences \& Applied Research, 4(2)

Mohammed, M. B. H, Saafi, S \& Farhat, A (2014). Testing the causal relationship between exports and Imports: Evidence from Tunisia, Journal of Economics \& Strategic Management of Business, 2 (1)

Nain Md_Zulguar \& Ahmad, W. (2010). Export led growth hypothesis in India: Some further evidences, The IUP Journal of Monetary Economics, $3 . \quad$ Retrieved from http://ideas.repec.org/e/pah $145 \mathrm{html}$

Omisakin, S (2009). The relationship between foreign trade and economic growth in Nigeria: An application of the ARDL Bounds testing approach, International Journal of Research in Social Sciences, 2(3)

Rahmaddi, R \& Ichihashi, M. (2011), Exports and economic growth in Indonesia: A causality approach based on multivariate error correction model, Journal of International Development \& Cooperation, $17(2)$

Sahni, P \& Atri, V.N (2012). Export-led growth in India: An empirical investigation, International Journal of Marketing \& Technology, 2(7), Retrieved from http://www.ijmra.us

Samad, A. (2011). Exploring exports and economic growth causality in Algeria, Journal of Economic \& Behavioural Studies, 2(3)

Shahbaz, M (2012). Does trade openness affect long-run growth? Cointegration, causality and forecast error variance decomposition tests for Pakistan, Paper No. 37391. Retrieved from http://mpra.ub.uni- muenchen.de/37391/MPRA

Sharma, A \& Panagiotidis, T (2005). An analysis of exports and growth in India: Co-integration and causality evidence, 1971-2001, Review of Development Economics, 9(2)

Shirazi, N. S \& Manap, T. A (2004). Export-led growth hypothesis: Further econometric evidence from Pakistan, Pakistan Development Review, 43

Taban, S \& Aktar, I (2008). An empirical examination of the export-led growth hypothesis in Turkey, Journal of Yasar University, 3(11)

Thurayia, S (2004). The relationship between exports and economic growth experience of Saudi Arabia and the Republic of Sudan, Economic studies: The Scientific Series of the Saudi Economic Association, $11(6)$

Toda, H .Y \& Philip, P. C (1993). Vector autoregression and causality: A theoretical overview and simulation study, Econometric Review, 13(2)

36. Toda, H.Y \&Yamamoto, T (1995). Statistical inference in vector autoregression with possibly integrated processes, Journal of Econometrics, 66. Retrieved from http://www.tcmb.gov.tr, 
Uduebe, C. C \& Okulegbe, B. E (1997). Exports and Nigerians economic growth: A co-integration analysis, Journal of Economics, 2(2), 23-30

Veulemans, F, (2012). International trade in Taiwan: An application of Toda and Yamamoto

non causality test on the export-led growth hypothesis for Taiwan during 1981-2011, National Taipei University of Technology

Whiteman, C H, P. M. Summers \& Riezman, R (1995). The engine of growth or its hand-maiden? A time series assessment of export led growth, Journal of Midwest International Economics, 2 (2)

$\mathrm{Xu}, \mathrm{Z}$ (1996). On the causality between export growth and GDP growth: An empirical re-investigation, Review of International Economics, 4(2)

41. Yelwa, M. \& Diyoke, K. O (2013). An empirical investigation of export-led growth amongst some selected ECOWAS countries: An alternative to FDI?, European Journal of Management Sciences E Economics, 1(1)

Yousif, K and Al-Yousif (1997). Exports and economic growth: Some empirical evidence from the Arab Gulf countries, Applied Economics, 29(6)

Zapata, N \&Rambaldi, E (2011). Testing for Granger non-causality in cointegrated systems made easy, Working papers in econometrics and applied statistics, 88, Department of Econometrics, University of New England 